\title{
Estimating Carbon Sequestration by Sugi (Cryptomeria japonica) Plantations According to Site and Management Conditions
}

\author{
Yoko Asada*1,2 and Satoshi Tatsuhara*1
}

\begin{abstract}
Carbon sequestration by plantation forests depends on the site conditions and silvicultural system used. This study estimated the spatial distribution of carbon sequestration by sugi (Cryptomeria japonica) plantations in a study area according to site quality and thinning regime. The study area was the University of Tokyo Forest in Chiba, which is located on the southern Boso Peninsula, Japan. Site index curves were created from height measurements in sugi plantation experimental plots. Sixty-five sampling points were located in sugi plantations, and the heights of three to five dominant trees around each sample point were measured. The site index was calculated for each sampling point, and the average height at 60 years of age was estimated from the average height at each sampling point using the site index curves. Site factors were calculated from a digital elevation model (DEM) in a geographic information system (GIS). Discriminant functions were developed from five site factors: slope, shaded relief, distance from a ridge, plan curvature, and the wetness index. The correctness rate was $60 \%$. In addition, stand growth was predicted for each site quality using LYCS ver. 2.32 under low thinning at frequencies of 1,2,3, and 5 times. Carbon sequestration was estimated from the growth of stand volume multiplied by the basic density, biomass expansion factors, ratio of total biomass to aboveground biomass, and carbon fraction. The estimated carbon storage and sequestration for the study area were mapped using GIS according to the site quality estimated from the five site factors and specified thinning regimes. The average carbon storage per hectare peaked at a thinning frequency of one. Thinning during the young stage increased carbon storage, although frequent and strong thinning regimes decreased carbon storage. The average carbon sequestration per hectare increased with thinning frequency because more frequent thinning leads to faster growth just after thinning in more stands. These maps enabled us to understand the change in carbon storage and sequestration over the study area according to the chosen silvicultural system.
\end{abstract}

Keywords: carbon sequestration, carbon storage, plantation forests, site quality, thinning regimes

\section{INTRODUCTION}

Global climate change is a concern throughout the world. Plantation forests are expected to help mitigate global warming by serving as carbon dioxide sinks. Thus, it is important to know the extent of carbon sequestration by such forest systems. Forest growth depends on site conditions and the type of silvicultural system used. Therefore, to evaluate the amount of carbon sequestration provided by plantation forests, the site conditions and silvicultural systems, especially thinning regimes, of individual stands must be examined. Site indices can be estimated from geographic or environmental factors using a geographic information system (GIS; IvERSON et al., 1997; CHEN and ABE, 1999; MrTSUdA et al., 2001; 2007). Moreover, GIS techniques play an important role in mapping the spatial distribu-
Corresponding author: Yoko Asada

E-mail: y.asada@murc.jp

${ }^{* 1}$ Graduate School of Agricultural and Life Sciences, the University of Tokyo, 1-1-1 Yayoi, Bunkyo-ku, Tokyo 113-8657, Japan
*2 Present address: Mitsubishi UFJ Research \& Consulting Co., Ltd., Shinagawa Grand Central Tower, 2-16-4, Konan, Minato-ku, Tokyo 108-8248, Japan 
tion of site quality.

Japanese cedar (sugi, Cryptomeria japonica D. DoN) is a major plantation species throughout most areas of Japan. Sugi plantations account for approximately $43 \%$ of the extent of plantation forests in Japan. The objectives of this study were, using GIS, to estimate the spatial distribution of carbon sequestration by sugi plantations based on site quality and thinning regime. We developed a model for estimating the site quality of sugi plantations from various environmental factors. In addition, stand growth was predicted for each level of site quality under various thinning regimes to map the spatial distribution of carbon storage and carbon sequestration in sugi plantations using GIS. This case study was conducted at the Tokyo University Forest in Chiba (hereafter, Chiba Forest).

\section{STUDY AREA}

The study area comprised sugi plantation forests in Chiba Forest, which is located in the southern part of the Boso Peninsula, Japan $\left(35^{\circ} 9-13^{\prime}\right.$ N, $140^{\circ} 6-10^{\prime}$ E; Fig. 1$)$. Most of the plantations in the region are sugi and hinoki cypress (Chamaecyparis obtusa [SIEB. et ZUCC.] ENDL.). Of the approximately 2,171 ha of Chiba Forest, 476.75 ha comprise sugi plantations. The ages of the plantations range from young to over-mature, and the oldest stand is approximately 160 years old. The elevation of the study area ranges from 50 to $370 \mathrm{~m}$ above sea level. The topographic features are complex, and the slope is generally very steep. The underlying rock consists of sandstone, conglomerate, mud stone, and tuff. The main soil type is brown forest soil, which is distributed throughout most parts of Chiba Forest. The monthly mean temperatures in midwinter and midsummer are around $4{ }^{\circ} \mathrm{C}$ and $20^{\circ} \mathrm{C}$, respectively. The annual mean temperature is about $14^{\circ} \mathrm{C}$, and annual precipitation varies from 2,000 to $2,400 \mathrm{~mm}$.

\section{METHODS}

Creation of a Site Index Curve from Height Measurements

In most studies, logistic, Mitscherlich, and GOMPERTZ functions are used as height growth curves or site index curves. These functions are useful for estimating site indices based on a key age of 40 years from average tree height at different ages. However, accurate estimates of the site index based on the average tree height of old stands are difficult to acquire, because the current site index curves were developed using data that did not include mature stands.

In this study, new site index curves that are more applicable to old stands were developed by applying data that included mature stands to select the best model results. Height measurements at eight experimental plots (TAKEuchI and HASEGAWA, 1975; SuzUKI et al., 1999) within sugi plantations were used for developing site index curves. A diameter-height curve was developed for each plot by applying the NÄsLund formula to diameter and height measurements of sample trees. The tree heights in each plot were calculated from diameter measurements with the diameter-height curve. Average height was calculated by averaging the heights of the 100 largest (based on diameter at breast height: DBH) trees per ha (ISHIBASHI, 2006). Six functions, the MitscherLICH, GOMPERTZ, logistic, RichaRdS, and two logistic-type functions, were applied to age-height data:

$$
\begin{aligned}
& H=k\left(1-a b^{t}\right), \\
& H=k a^{b^{2}}, \\
& H=\frac{k}{1+a \exp (-b t)},
\end{aligned}
$$

(1)
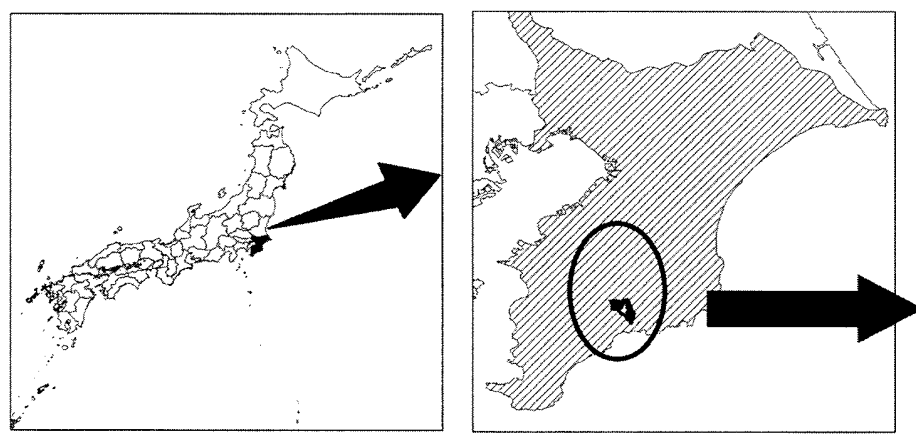

Fig. 1 Location of the study area

(1) Japan, (2) Chiba Prefecture, (3) The University of Tokyo forest in Chiba. Black areas in (3) depict sugi plantations.
(2)

(3)

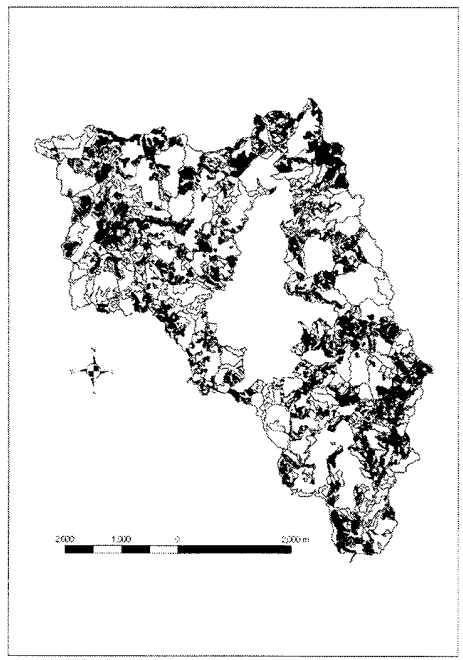




$$
\begin{aligned}
& H=k(1+\exp (a t))^{\frac{1}{1-b}}, \\
& H=\frac{k}{1+\exp (a+b \ln (1+t))}, \\
& H=\frac{S I(1+\exp (a+b \ln (60+c)-\ln S I))}{1+\exp (a+b \ln (60+c)-\ln S I)},
\end{aligned}
$$

where $H$ is dominant height, $t$ is stand age, SI is the site index, and $a, b, c$, and $k$ are parameters. Equations (5) and (6) are modified logistic functions that showed favourable performance for lodgepole pine (Pinus contorta) secondary forests in Alberta Province, Canada (Huang, 1999; Meng and Huang, 2009).

Because Equation (6) includes the site index as an independent variable, root mean square error (RMSE) and AKAIKE's information criteria (AIC) were calculated directly from the applied data, as shown in Equations (7) and (8):

$$
\begin{aligned}
& \mathrm{RMSE}=\sqrt{\frac{\sum_{i=1}^{n}\left(x_{i}-\hat{x}_{i}\right)^{2}}{n}}, \\
& \mathrm{AIC}=n\left(\ln 2 \pi \frac{\sum_{i=1}^{n}\left(x_{i}-\hat{x}_{i}\right)^{2}}{n}+1\right)+2(p+1),
\end{aligned}
$$

where $n$ is the number of data, $p$ is the number of parameters in the model, $x_{i}$ is the observed value, and $\hat{x}_{i}$ is the estimated value. Parameters for the five other equations were obtained, and the fit equations were used as guide curves to develop site index curves. Parameter $k$ was modified for each experimental plot, so that the value of the equations at a base age of 60 years was equal to the estimated average height at that age. The RMSE and AIC were then calculated.

\section{Development of a Model to Estimate Site Quality}

Twelve sample slopes were selected in sugi plantations to include various slope aspects. Sampling points were established about every $20 \mathrm{~m}$ along the slopes. As a result, 65 sampling points were located in the sugi plantations, and the heights of 3 to 5 dominant trees around each point were measured (TATsuHARA, 2008). The average height of the dominant trees at 60 years of age was calculated for each sampling point from the dominant height at each sampling point using the site index curves. Then, sampling points were classified into five site qualities, based on their height at 60 years of age according to the following classification: site quality $1,>26 \mathrm{~m}$; site quality 2 , 22-26 m; site quality $3,19-22 \mathrm{~m}$; site quality $4,17-19 \mathrm{~m}$; site quality $5,<17 \mathrm{~m}$, based on the yield tables for sugi in Chiba Forest constructed by NAGUMo et al. (1981).

The GIS software ArcGIS 9.3 (ESRI) including ArcInfo Workstation 9.3 (ESRI) was used in this study. Contours were digitised from 1:5,000 orthophotographs. A digital elevation model (DEM) was created for the study area by interpolating the altitude of each grid cell from the contours and adding spot heights of mountaintops using the method of HuTCHINSON (1989). The spatial resolution of the DEM was set at $20 \times 20 \mathrm{~m}$.

The site productivity of stands is affected by site factors such as soil properties as well as topographic and climatic features. Assuming a reasonably similar climate, elevation, disturbance history, and soil fertility among sites, variation in productivity will be driven primarily by moisture availability (Iverson et al., 1997). Topographic features, such as slope steepness, aspect, and slope position, as well as solar radiation, influence soil moisture levels. Therefore, eight environmental factors (slope, flow accumulation, three types of curvature, the wetness index, distance from a ridge, and shaded relief) were used as possible predictor variables to estimate the site index; the three types of curvature were plan curvature, profile curvature, and curvature (plan curvature-profile curvature). These factors were chosen because they were easily calculated on the basis of the DEM and GIS. The first seven variables describe hydrologic characteristics, whereas shaded relief describes the level of solar radiation.

The slope describes overland and subsurface flow velocity and runoff rate (Moore et al., 1991) and was calculated as the average of the slope angle measurements for the upper and lower side of each point, excluding edge points. In the GIS, the slope was estimated for each cell from the DEM.

Flow accumulation is a measure of the surface or shallow subsurface runoff at a given point on the landscape and integrates the effects of the upslope-contributing area and catchment convergence and divergence on runoff (MooRE et al., 1991). The specific catchment area was calculated by counting the number of upstream cells for each cell in the DEM (JENSON and Domingue, 1988).

The curvature represents the shape of the landscape, whether flat, convex, or concave, and was calculated for each cell from surrounding cells on the DEM. A value of zero indicates a flat surface. The more convex or concave a surface, the larger its absolute value is. ZASLAVSKY and SinAI (1981) observed that soil water content was related to curvature.

The wetness index was a compound topographic index representing soil water content and surface saturation zones (MOORE et al., 1991). The index was defined as:

Wetness index $=\ln (A / \tan \beta)$,

where $A$ is flow accumulation +1 and $\beta$ is the slope angle, assuming uniform soil properties.

The shaded relief map represents the hypothetical illumination values of a surface in relation to neighbouring cells by setting a position for a hypothetical light source. Shaded relief is a relative value that varies from 0 to 255 and represents the effect of the intensity of solar radiation on the drying of soil. A solar azimuth of 202 degrees and a solar altitude of 45 degrees were used for the light position. We chose this solar azimuth because maximum drying of soil occurs on aspects 
Table 1 Assessed thinning regimes

\begin{tabular}{cccc}
\hline No. & Frequency & $\begin{array}{c}\text { Stand age at time of } \\
\text { thinning (years) }\end{array}$ & $\begin{array}{c}\text { Strength of thinning (\% of } \\
\text { thinned trees to the total) }\end{array}$ \\
\hline 1 & 1 & 25 & 30 \\
2 & 2 & 25,40 & 30,30 \\
3 & 3 & $25,40,70$ & $30,30,40$ \\
4 & 5 & $25,35,50,70,90$ & $30,30,30,30,30$ \\
\hline
\end{tabular}

Table 2 Root mean square errors (RMSE) and AKAIKE's information criteria (AIC) of the applied growth functions

\begin{tabular}{ccc}
\hline Growth functions & RMSE & AIC \\
\hline Equation (1) & 1.3978 & 534.15 \\
Equation (2) & 1.5572 & 566.54 \\
Equation (3) & 1.7948 & 609.14 \\
Equation (4) & 1.4879 & 552.90 \\
Equation (5) & 1.3734 & 528.88 \\
Equation (6) & 1.2364 & 499.34 \\
\hline
\end{tabular}

slightly west of south (SSW) due to the added drying potential of higher afternoon temperatures (IVERSON et al., 1997), although maximum cumulative solar radiation over a year occurs on steep, south-facing slopes (LEE and BAUMGARTNER, 1966). We chose this solar altitude because it approximates the growing season average (IVERSON et al., 1997).

The distance from a ridge was calculated using values of flow accumulation. We inverted the DEM data and applied an ArcGIS spatial analyst "flow accumulation" function. Then, we chose several points at which the value of flow accumulation was large to represent ridges, and the distance from a ridge to a sampling point was calculated.

The locations of the 65 sampling points were imported into the GIS, and the abovementioned site factors at each sam pling point were obtained from their layers. Using discriminant analysis, a discriminant function with suitable site factors was developed to estimate site quality in the study area from the site quality and site factors at the 65 sampling points.

Prediction of Carbon Storage and Sequestration by Sugi Plantations

The volume growth of sugi plantations was predicted using the stand growth prediction system LYCS ver. 2.32 (Matsumoto, 1997). Site index curves in LYCS were replaced with the new ones developed in this study. Density at 20 years of age was set at 3,000 trees/ha, and four thinning regimes were assessed (Table 1). The level of thinning was assumed to be low for the four regimes. In thinning regime no. 1, pre-commercial thinning was conducted at a young age, and then no operations were conducted. In thinning regime no. 2, commer cial thinning was conducted in addition to the thinning in regime no. 1 , after which no operations were conducted. In thinning regime no. 3 , old-age commercial thinning was added to thinning regime no. 2. Thinning regime no. 4 was intensive, and thinning was conducted frequently until an old age. Carbon storage and sequestration in sugi plantations were predicted from the stand volume and its growth for each site quality and thinning regime using the following equation:

$$
y=v \times b \times B E F \times r \times c,
$$

where $y$ is carbon weight $(\mathrm{t}), v$ is stand volume $\left(\mathrm{m}^{3}\right), b$ is basic density $\left(0.314 \mathrm{t}-\mathrm{dm} / \mathrm{m}^{3}\right), B E F$ are biomass expansion factors $(1.57$ at ages $\leq 20$ years and 1.23 at ages $>20$ years), $r$ is the ratio of total biomass to aboveground biomass (1.25), and $c$ is the carbon fraction (0.5 t-C/t-dm) (GOVERNMENT OF JAPAN, 2009). The volume of dead and thinned trees was excluded from volume growth.

Mapping the Spatial Distribution of Carbon Storage and Sequestration

Site quality in the study area was estimated by the discriminant functions based on raster data using GIS. The carbon storage and sequestration distributions were mapped using GIS according to the estimated site quality and specified thinning regimes. Moreover, their average values in the Chiba Forest sugi plantations were calculated.

\section{RESULTS}

Site Index Curves

Equation (6) was chosen as the best site index function 
Table 3 Discriminant functions to estimate site quality from site factors

\begin{tabular}{lcccc}
\hline & \multicolumn{4}{c}{ Discriminant coefficients } \\
\cline { 2 - 5 } Variable & Function 1 & Function 2 & Function 3 & Function 4 \\
\hline Slope & 0.0471 & 0.0755 & -0.0575 & -0.0436 \\
Shaded relief & -0.0141 & 0.0038 & -0.0016 & 0.0190 \\
Distance from ridge & 0.0623 & -0.0023 & 0.0416 & 0.0423 \\
Plan curvature & 0.5314 & 0.3773 & 1.2106 & -0.0370 \\
Wetness index & 0.6142 & -0.4679 & -0.1351 & -0.3759 \\
\hline Constant term & -1.0595 & -1.4576 & 0.7822 & -2.2863 \\
\hline
\end{tabular}

because it produced the smallest AIC of the six functions (Table 2). The estimated parameters of Equation (6) were as follows:

$$
a=8.285, b=-1.22, c=16.195 .
$$

This function proved more suitable for old growth forests than the currently available site index curves.

\section{Site Factors}

Discriminant functions to estimate site quality were developed from five site factors: slope, shaded relief, distance from a ridge, plan curvature, and the wetness index (Table 3). The correctness rate of the discriminant functions was $60 \%$. For each cell, site quality was mapped with GIS using the discriminant functions for the five factors (Fig. 2).

\section{Carbon Storage and Sequestration}

Comparison 1. Carbon storage under various thinning regimes

Carbon storage peaked at a thinning frequency of 1 (Figs. 3 and 4). Thinning during the young stage increased carbon storage in plantation forests, whereas strong and frequent thinning regimes decreased carbon storage.

Comparison 2. Carbon sequestration under various thinning regimes

Carbon sequestration increased with thinning frequency, because more frequent thinning led to rapid growth just after thinning in more stands (Figs. 5 and 6).

\section{Comparison 3. Carbon storage over time}

Carbon storage was simulated under the assumption that sugi stands were not replanted or cut during the simulation. Carbon storage increased over time under conditions of moderate thinning (Figs. 7 and 8).

\section{DISCUSSION}

The growth of sugi is affected not only by age and genetics but also by site conditions such as soil fertility and mois-

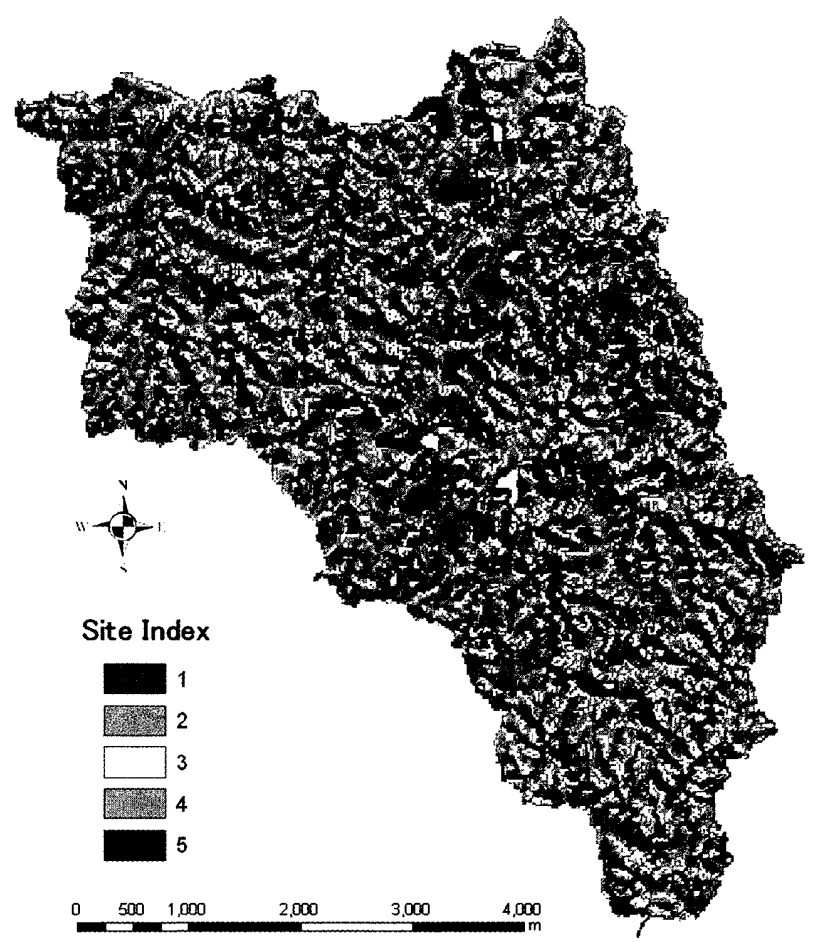

Fig. 2 Distribution of the site index estimated from site factors

ture. In other words, even at the same age, trees may grow at different rates depending on their slope positions (TAKESHITA, 1964). The method used here to estimate site quality for sugi plantations using site factors derived from DEM data can easily be applied more broadly. Thus, this approach would be helpful for evaluating future carbon sequestration.

The results indicated that the study area still absorbs carbon. At high quality sites, sugi stands continue to grow even after reaching maturity (NISHIzONO et al., 2008). The current study area contains many sugi plantation areas of good quality. These results are consistent with the results of NisHizono et al. (2008).

The results of this study also indicated that the more frequently plantation forests were thinned, the more carbon was absorbed by the forests. Thinning can contribute to increases 

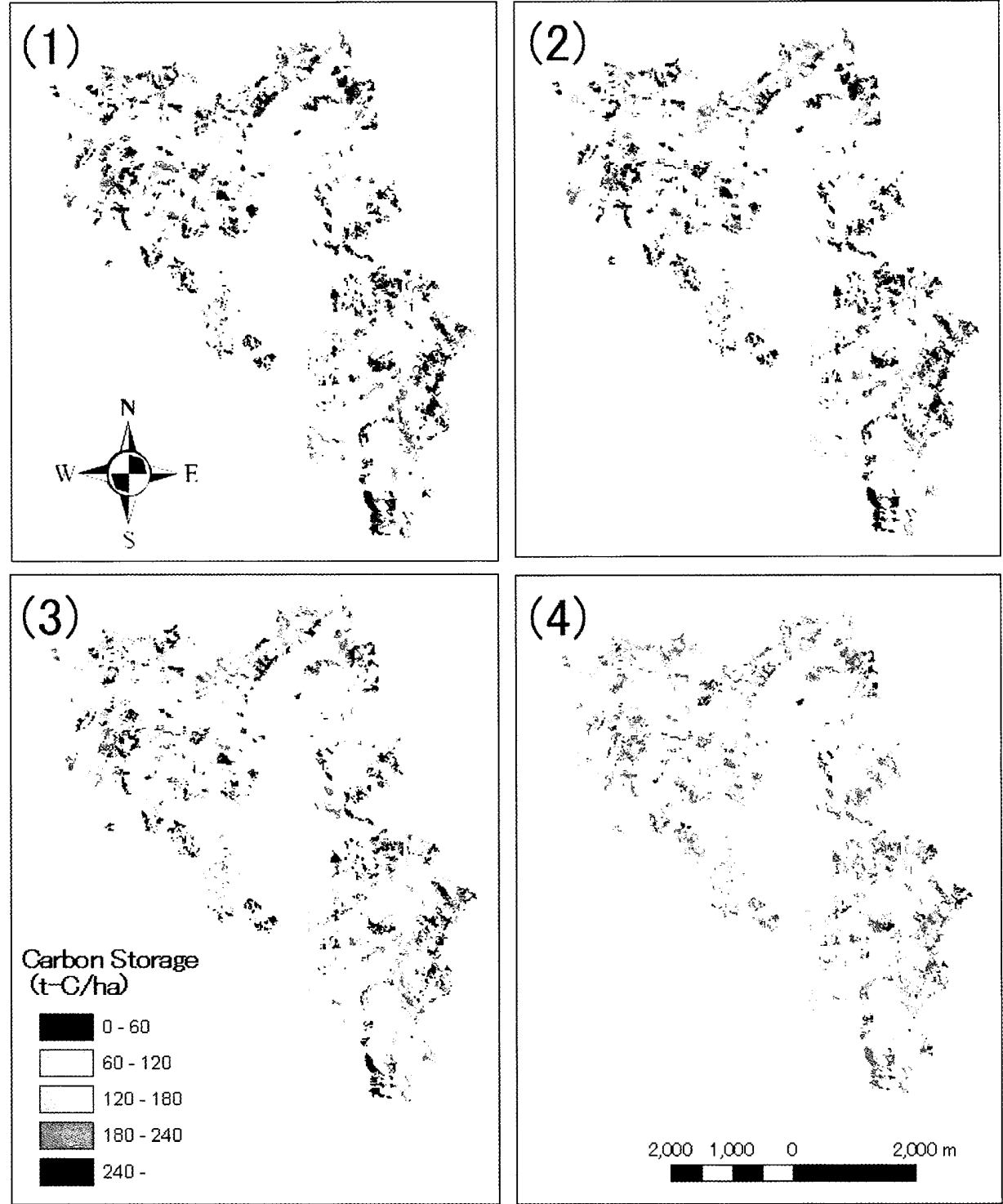

Fig. 3 Distribution of carbon storage under thinning regimes: (1) no. 1, (2) no. 2, (3) no. 3, and (4) no. 4

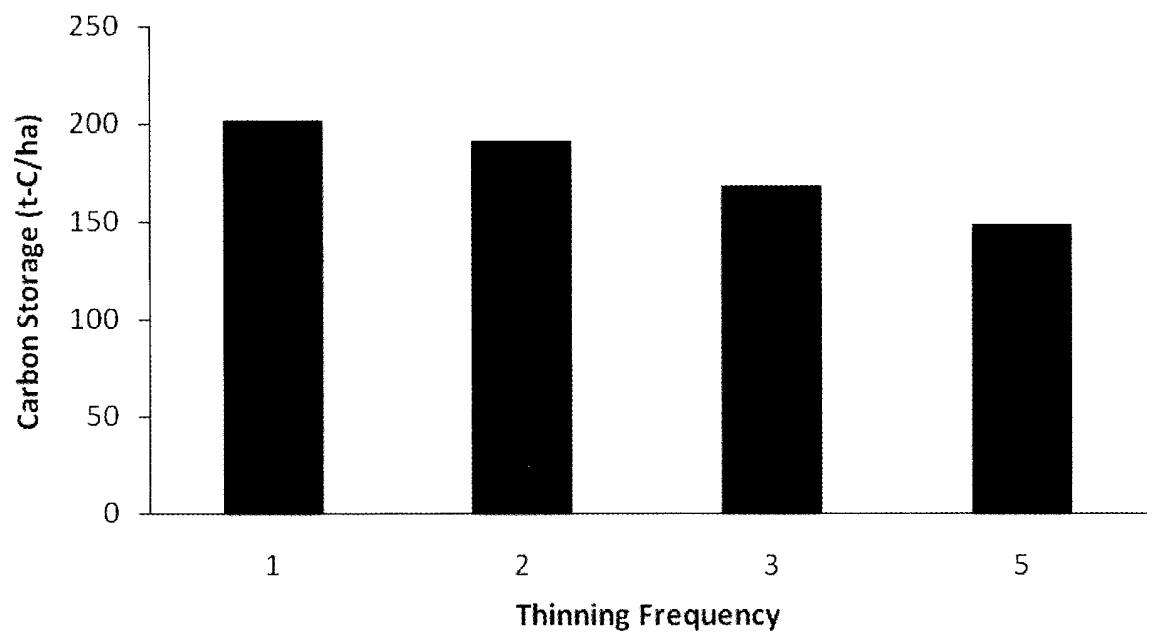

Fig. 4 Carbon storage under the four thinning regimes for all sugi plantations in Chiba Forest 

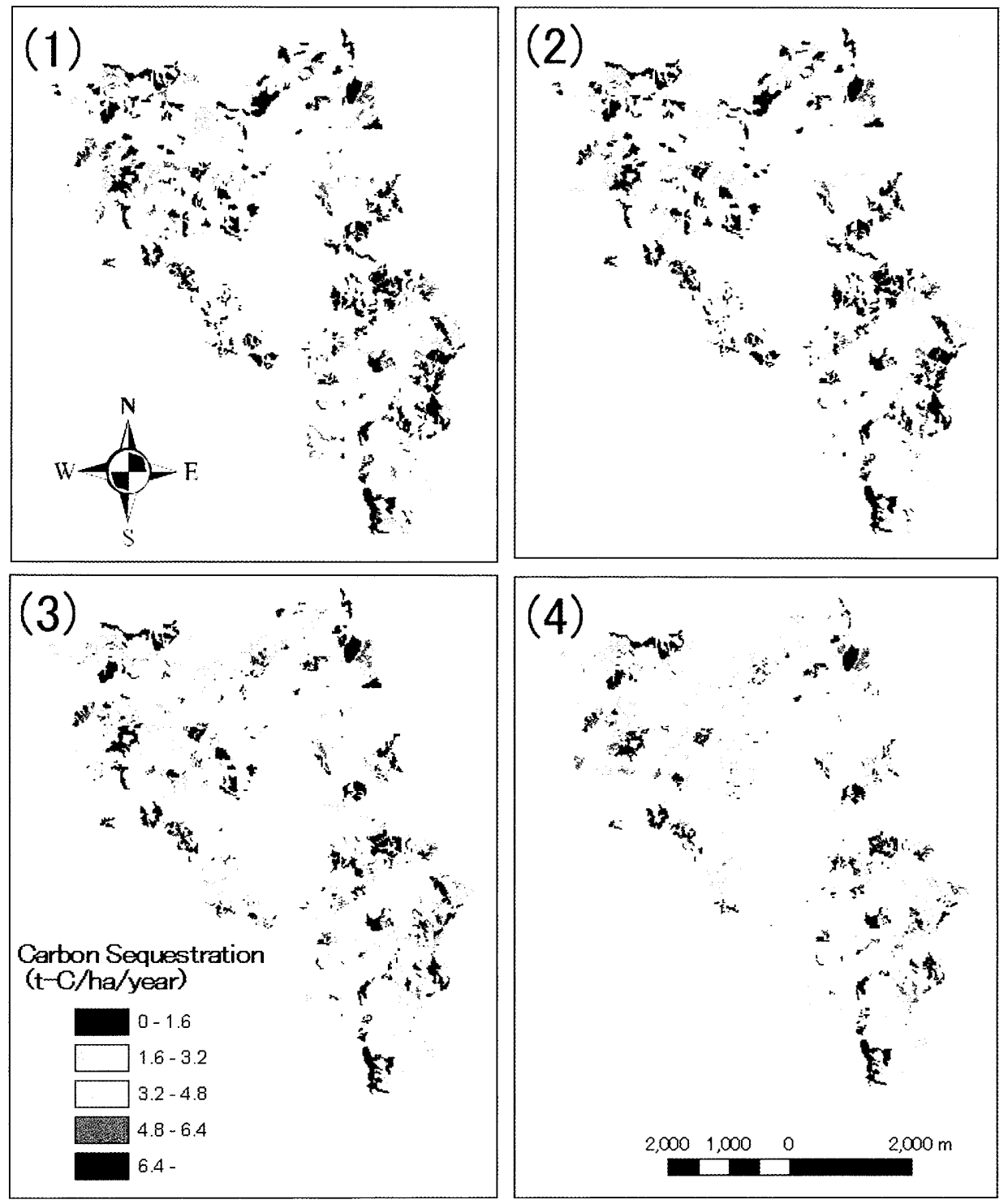

Fig. 5 Distribution of carbon sequestration under thinning regimes: (1) no. 1, (2) no. 2, (3) no. 3, and (4) no. 4

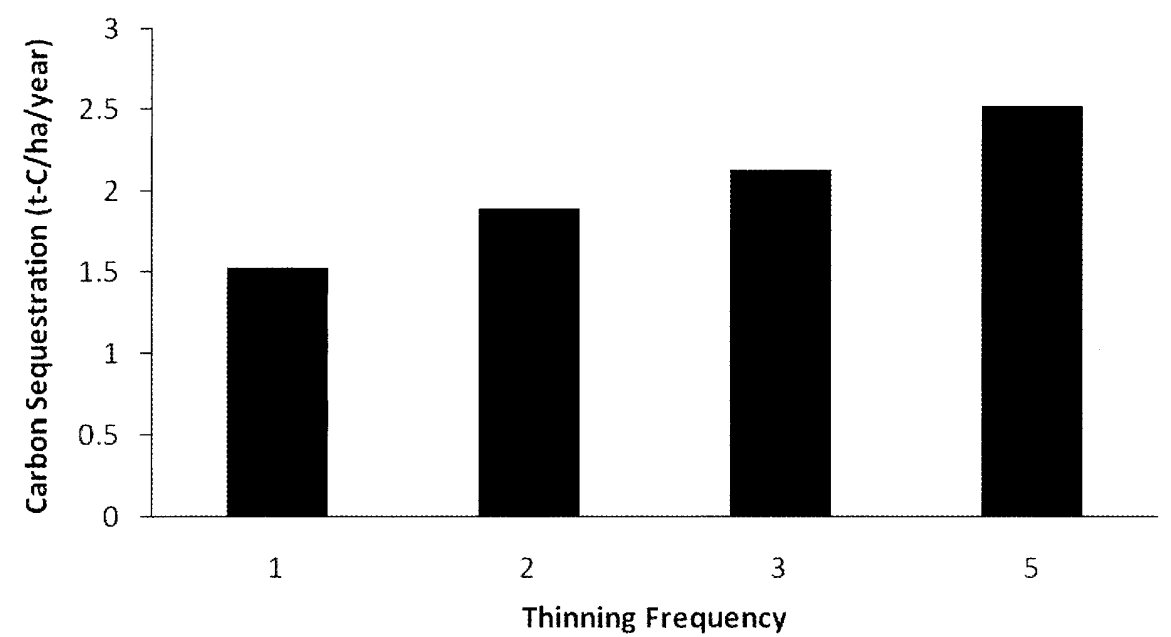

Fig. 6 Carbon sequestration under the four thinning regimes for all sugi plantations in Chiba Forest 


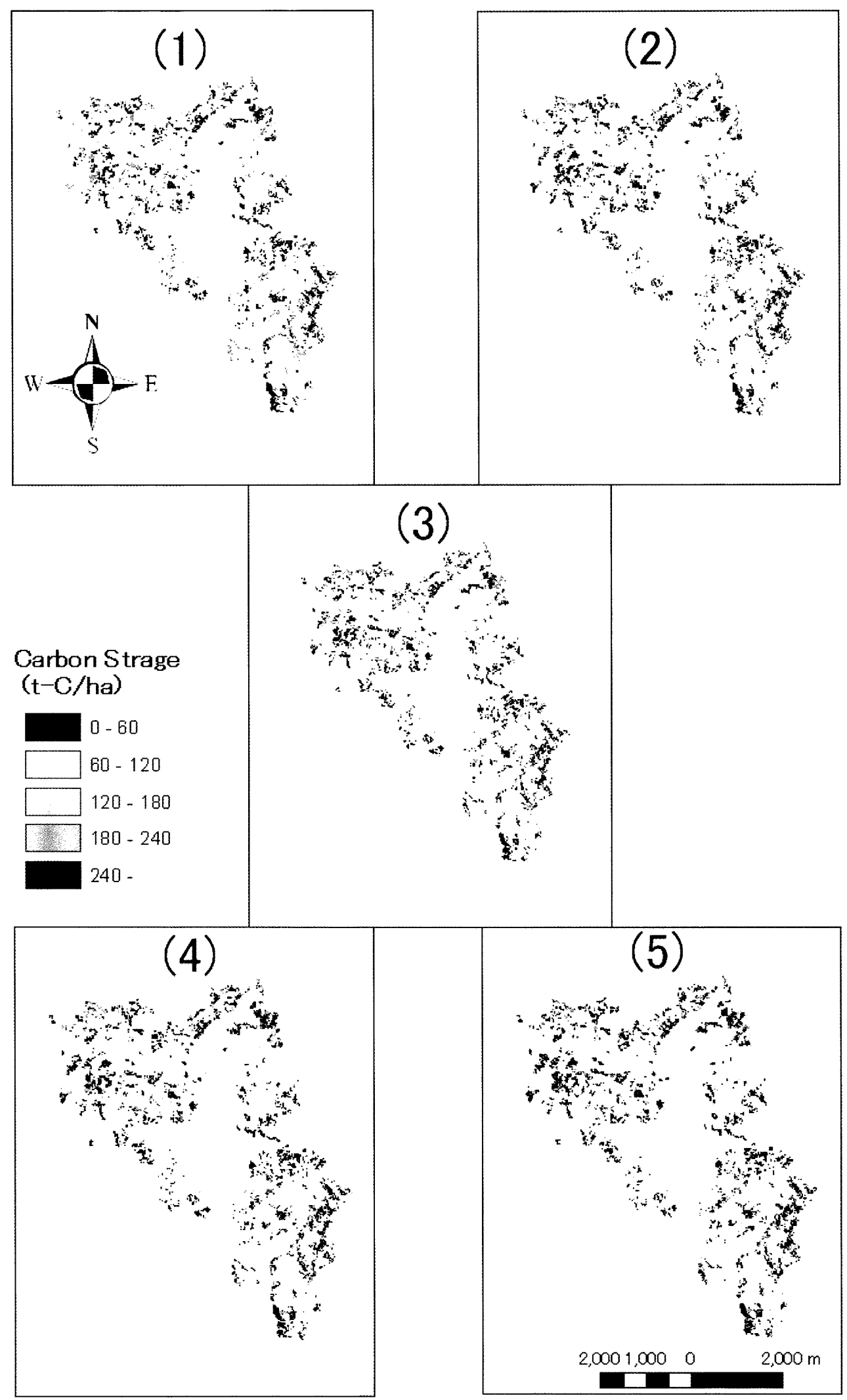

Fig. 7 Change in the distribution of carbon storage under thinning regime no. 1 over time (years): (1) at present, (2) after 10 years, (3) after 20 years, (4) after 30 years, and (5) after 40 years 


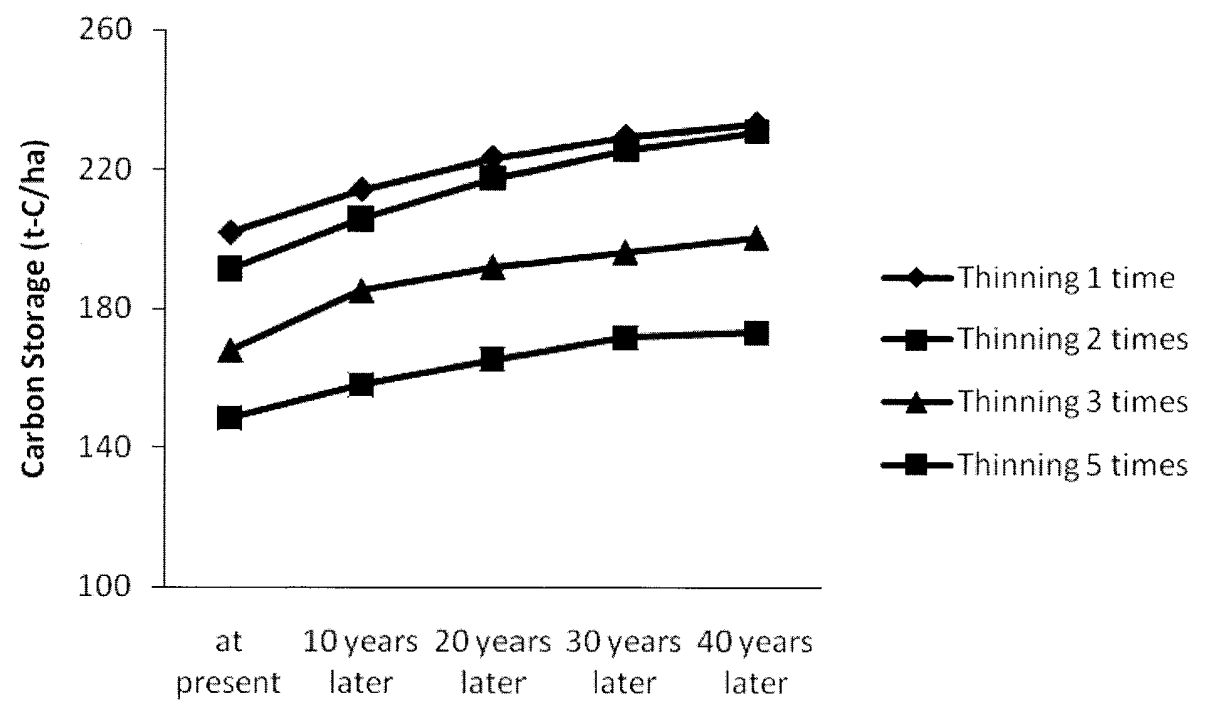

Fig. 8 Change in average carbon storage per unit area for all sugi plantations in Chiba Forest over time (years)

in carbon sequestration because trees require space to grow and the process of thinning creates the necessary space. Moreover, dead trees include those that died due to competition for light or sudden disturbances, such as damage from wind and snow (NisHzono et al., 2008). Thus, thinning should be conducted frequently, at least in the short term, to cull suppressed trees and, in turn, increase levels of carbon sequestration. However, thinned trees ranged in age from young (20 years old) to old (70 to 90 years old), and DBH can increase just after thinning in trees even older than 60 years old (Osum et al., 2000). Thus, thinning remains effective even in old plantation forests; it avoids declines in the growth of DBH caused by canopy closure and increases the number of large trees (KUNISAKI et al., 1999).

This study demonstrated that frequent thinning can increase carbon sequestration but can also decrease carbon storage. Although thinning promotes the growth of remaining trees, strong thinning can decrease the growth of stand volume in plantation forests (KoSAKA et al., 1967; ArBA et al., 1988). Because the growth rate of trees can decline, particularly in old plantation forests, managers should avoid reducing stand growth through strong thinning (Osumi et al., 2000). Therefore, the strength of thinning should be chosen carefully so as to maximise the growth of remaining trees and minimise decreases in stand growth.

\section{CONCLUSION}

In this study, the site quality of plantation forests in terms of carbon sequestration was estimated using only site factors. Using the models presented here, site quality can be determined for treeless areas intended for future sugi plantations as well as for extant sugi plantations. Using GIS, the estimated carbon storage and sequestration for the study area were mapped, and a stand growth prediction system was designed based on estimated site quality and specified thinning regimes. The model can estimate not only present but also future carbon sequestration. DEM maps described changes in carbon storage and sequestration throughout the study area with various selected silvicultural systems or over time. The modelling and mapping approach presented here will prove useful for future evaluations of carbon sequestration in a variety of forest ecosystems.

\section{ACKNOWLEDGEMENTS}

We thank the Tokyo University Forest in Chiba for providing the experimental plot data. We thank Dr. Makoto SuzuKI and Mr. Masanori SuzukI at the Tokyo University Forest in Chiba and Mr. Shin-ichi ITo at Niigata University for assistance with field measurements at the sampling points.

\section{LITERATURE CITED}

Aiba, Y., Haibara, K. and Enomoto, K., (1988): Studies on the thinning for the selection of final cutting trees in sugi young stand. Bull. Exp. For. Tokyo Univ. Agric. Tech. 25: 19-28 (in Japanese with English summary)

Chen, J. and ABE, N., (1999): Site classification for sugi plantations using GIS. J. For. Plann. 5: 1-8

GOVERNMENT OF JAPAN, (2009): Report on Japan's supplementary information on LULUCF activities under article 3, paragraphs 3 and 4 of the Kyoto protocol. The Government of Japan, Tokyo, 66pp

HuANG, S., (1999): Development of compatible height and site index models for young and mature stands within an eco- 
system-based management framework. In: AMARO, A. and Tomé, M. (eds) Empirical and process-based models for forest tree and stand growth simulation. Ediçoes Salamandara, Lisbon: $61-98$

HuTCHINSON, M. F., (1989): A new procedure for gridding elevation and stream line data with automatic removal of spurious pits. J. Hydrol. 106: 211-232

ISHIBASHI, S., (2006): Explanation of forest and forestry terms: Site quality, site index, and mean height of dominant and codominant trees*. Northern Forestry, Japan 58: 286 (in Japanese)

Iverson, L. R., DALE, M. E., ScotT, C. T. and Prasad, A., (1997): A GIS-derived integrated moisture index to predict forest composition and productivity of Ohio forest (U.S.A). Landscape Ecol. 12: 331-348

Jenson, S. K. and Domingue, J. O., (1988): Extracting topographic structure from digital elevation data for geographic information system analysis. PE \& RS 54: 1593-1600

Kosaka, J., Terasaki, Y., Tsuzuki, K. and Kin, T., (1967): Thinning method based on stand growth*. Trans. Mtg. Jpn. For. Soc. 78: 60-61 (in Japanese)

Kunisaki, T., Waragaya, N. and Shibata, N., (1999): Stand structure and growth of an old Cryptomeria japonica stand at the base of Mt. Iwate, northern Japan. J. Jpn. For. Soc. 81: 346-350 (in Japanese with English summary)

LeE, R. and Baumgartner, A., (1966): The topography and insolation climate of a mountainous forest area. For. Sci. 12 258-267

Matsumoto, M., (1997): Construction of yield tables for sugi (Cryptomeria japonica) in Kumamoto district using LYCS. J. For. Plann. 3: 55-62

Meng, X. S. and Huang, S., (2009): Improved calibration of nonlinear mixed-effects models demonstrated on a height growth function. For. Sci. 55: 238-248

Mitsuda, Y., Ito, S. and SaKamoto, S., (2007): Predicting the site index of sugi plantations from GIS-derived environmental factors in Miyazaki Prefecture. J. For. Res. 12: 177-186

Mitsuda, Y., Yoshida, S. and Imada, M., (2001): Use of GISderived environmental factors in predicting site indices in Japanese larch plantations in Hokkaido. J. For. Res. 6: 87-93

Moore, I. D., Grayson, R. B. and Ladson, A. R., (1991): Digital terrain modelling: A review of hydrological, geomorphologi- cal, and biological applications. Hydrol. Process. 5: 3-30

Nagumo, H., Shiraishi, N. and TanaKa, M., (1981): Systematic method constructing an yield table for sugi even-aged stand: A case study in experimental plots of the Tokyo University Forest in Chiba. Bull. Tokyo Univ. For. 71: 269-330 (in Japanese with English summary)

Nishizono, T., Tanaka, K., Awaya, Y., Oishi, Y., Hayashi, M., Yokota, Y., Amano, M., Kuboyama, H., Yamaki, K. and Furuido, H., (2008): Age-related changes in stand volume growth of Cryptomeria japonica plantations in Akita District, northeastern Japan. J. Jpn. For. Soc. 90: 232-240 (in Japanese with English summary)

Osumi, K., Mori, M., Sakurai, S., Saitou, K., Satou, S. and SEKI, T., (2000): Long term growth records of old-aged sugi (Cryptomeria japonica) plantations in Akita Prefecture, northeastern Japan. J. Jpn. For. Soc. 82: 179-187 (in Japanese with English summary)

Suzuki, M. Tatsuhara, S., Yamanaka, C., Karakama, I. and IDE, Y., (1999): Records on the growth of stands in the Tokyo University Forest in Chiba II: Development of the stands from 1976 to 1996. Misc. Inf. Tokyo Univ. For. 38: 1-71 (in Japanese)

TAKESHITA, K., (1964): The formation of mountain slope and its meaning to the forestry. Bull. Fukuoka Pref. For. Exp. Sta. 17: 1-109 (in Japanese with English summary)

TaKeuch, K. and HaSegawa, S., (1975): Records on the growth of stands in the Tokyo University Forest in Chiba. Misc. Inf. Tokyo Univ. For. 19: 69-175 (in Japanese)

TAtsuhara, S., (2008): Zoning sugi (Cryptomeria japonica) plantations into silvicultural systems. In: TAKAHASHI, N., FENG, F. and NoBori, Y. (eds) Toward the establishment of the multipurpose and long-term forest management plans. Japan Society of Forest Planning Press, Utsunomiya: 29-36

Zaslavsky, D. and SinAI, G., (1981): Surface hydrology: I explanation of phenomena. J. Hydraul. Div., Proc. Am. Soc. Civil Engrs. 107: 1-16

*These English titles are tentative translations from the original Japanese titles by the authors of this paper.

(Received 23 September 2009) (Accepted 8 March 2010) 